\title{
Affiliation, Reciprocal Relationships and Peer Pressure in Knowledge Sharing in Public Universities in Malaysia
}

\author{
See-Kwong Goh ${ }^{1} \&$ Manjit-Singh Sandhu ${ }^{2}$ \\ ${ }^{1}$ Taylor's Business School, Taylor's University, Selangor, Malaysia \\ ${ }^{2}$ Department of Management, Monash University, Sunway Campus, Malaysia \\ Correspondence: See-Kwong Goh, Taylor's Business School, Taylor's University, Selangor, 47500, Malaysia. \\ Tel: 60-3-5629-5658. E-mail: seekwong.goh@taylors.edu.my; goh.seekwong@gmail.com
}

\author{
Received: January 31, 2013 Accepted: March 24, 2013 Online Published: June 1, 2013 \\ doi:10.5539/ass.v9n7p290 URL: http://dx.doi.org/10.5539/ass.v9n7p290
}

\begin{abstract}
The aim of this study was to examine the influence of some dimensions of social capital toward knowledge sharing intention. The theoretical framework and measurement tool was derived based on the three factors of social capital dimension (sense of affiliation, reciprocal relationships and peer influence) and knowledge sharing intention. A survey was conducted and obtained a total of 235 valid respondents. The theoretical model was examined using structural equation modeling. The findings confirm that employees with high sense of affiliation and reciprocal relationships are more willing to conform to social pressure in sharing their knowledge. The results also confirm that peer pressure in the public institution will result to higher propensity in knowledge sharing among colleagues and peers.
\end{abstract}

Keywords: affiliation, reciprocal relationships, peer pressure, knowledge sharing behavior, Malaysian Universities

\section{Introduction}

Knowledge is seen as one of the 'most strategically important resource' that organizations own (Grant, 1996). Davenport and Prusak (1998) went one step further by reiterating that knowledge assets due to their intangibility are difficult to imitate and replicate and are therefore more important than tangible resources. Ownership of knowledge assets are thus seen as a source of long term sustainable competitive advantage. In the context of higher education, universities are considered as knowledge based organizations due to their role as the epitome of knowledge development and management. For instance, sharing knowledge helps academics to enhance teaching ability, develop quality research and avoid repeating mistakes done in the past (Christensen, 2007). Despite the many benefits of sharing knowledge, academics often see knowledge sharing as ambiguous and equivocal. This is due to sharing knowledge requires additional effort and time beyond the requirement of their job. As such, unwillingness to share knowledge is one of the main impediments of knowledge sharing.

In Malaysia, public institutions have dominated the higher education industry for many years until recently where Malaysia is aiming to be the education hub in South East Asia which is line with the national objective of transforming Malaysia into knowledge based economy. Public institutions are facing tremendous threat from private institutions in maintaining its strategic position and also the decreasing funding by the government to support its operations. Many academics are leaving the public institutions to join the private institutions where the remuneration package is more attractive. For future growth and enhancement in public institution, knowledge sharing is exceptionally crucial. Public institutions must encourage and cultivate knowledge sharing among its employees to further develop and sustain in the market.

Knowledge sharing is based on the voluntary and willingness of an individual to share his or her knowledge. However, prior research mainly focused in the technology and systems aspect of knowledge sharing and little emphasis has been placed on individual's inclination to share knowledge with other employees in the organization (Hong, Suh, \& Koo, 2011). More specifically, there is little research that investigates the influence of sense of affiliation, reciprocal relationships and peer pressure towards knowledge sharing. Prior researchers have examined the influence of affiliation and reciprocity towards knowledge sharing attitude and intention (Bock, Zmud, Kim, \& Lee, 2005; S. Liao \& Chou, 2012). No one has examined these factors toward social 
pressure in knowledge sharing. These three factors are part of a large social capital theory. Social capital factors help to facilitate activities within the organisation and these three factors often act as intrinsic motivational forces in an organization (Bock et al., 2005). Since knowledge sharing requires human interaction, social bonding and peer influence, we believe that these factors are crucial to facilitate knowledge sharing in an organization. As such, this research seeks to investigate deeper on the impact of these factors towards knowledge sharing in the context of public institution in Malaysia. The research questions for this research focus on the underexplored aspect of knowledge sharing via reciprocal relationships, sense of affiliation and peer pressure.

1) Do affiliation and reciprocal relationships affect peer pressure towards knowledge sharing?

2) Does peer pressure affects knowledge sharing intention?

\section{Literature Review and Hypotheses}

\subsection{Knowledge Sharing}

Valuable complex knowledge is created via interaction between individuals and through accumulation of personal experience. This knowledge resides in the mind of the individual. Such knowledge is mostly tacit in nature. Tacit or implicit knowledge refers to knowledge that lives and sticks in a person's mind (Markus, 2001). This type of knowledge is normally deeply embedded in individuals (Janson \& McQueen, 2007) and is hard to quantify and can be lost easily when employees leave organizations. The willingness of organizational members to share and use tacit knowledge may depend on the extent that co-workers are trusted recipients and sources (Lucas \& dt ogilivie, 2006). Alternatively, explicit knowledge is easily understood, expressed and shared among the members in the organization (Biggam, 2001; Girard, 2006). Some authors referred to explicit knowledge as information that is specific and could be easily encoded into other means (Bartol \& Srivastava, 2002; Blacker, 1995). It is important for organizations to make sure tacit knowledge is retained within the organization through the development of proper knowledge sharing practices.

\subsection{Peer Pressure towards Knowledge Sharing}

Peer pressure is regarded as individuals' concerns about whether they should or should not conform to the other's expectation and opinions (Ajzen, 1991; Goh \& Sandhu, 2013). If an individual perceived what is to be apparent that his or her behavior is highly regarded by others who are regarded with importance to him or her, then the individual is believed to be motivated with higher intentions to pursue the said behavior (So \& Bolloju, 2005). Moreover, when individuals take part in a social system, like an organization, they tend to act as anticipated by their colleagues (Hsu \& Lin, 2008). Consequently, it is important to take into consideration social pressures or influences when investigating knowledge sharing behavior within organizations.

Previous researchers indicated that there is a positive relationship between peer pressure and behavioral intention (Harding, Mayhew, Finelli, \& Carpenter, 2007; Venkatesh, Morris, Davis, \& Davis, 2003). This implies that one will have a higher tendency to share his or her knowledge if the individual perceives conforming to the social norm is crucial. For example, an individual has higher intention to share when the individual perceive sharing among colleagues is highly regarded by his or her superior. From the empirical findings of Lin and Lee (2004), and Kuo and Young (2008), they claimed that high social norm does lead to high intention toward knowledge sharing. Thus we hypothesize:

H1: The higher the peer pressure towards knowledge sharing, the higher the intention to share knowledge.

\subsection{Affiliation}

A climate of affiliation is defined as "the perception of as sense of togetherness among an organization's members, reflects the caring and pro-social behavior critical to inducing an organization's members to help one another" (Bock et al., 2005, p.94). Chay, Loh, Menkhoff and Evers (2005) contended that a pro social behavior encourages one to volunteer to assist those they like and feel compatible with. In other words, the sense of affiliation measures the feeling of togetherness or closeness with other members. These feelings are developed based on the care and warmth received by him or her during needy times. As such, strong affiliation in the organization encourages employees to go beyond their responsibility to help each other in the organization (Bock \& Kim, 2002).

Employees with high affiliation tend to be more concerned on the feelings, thoughts and viewpoint of other colleagues (Bock et al., 2005). As a result, those with high sense of affiliation will develop a strong bond with others, such as friendship, and increase social interaction (Cardador \& Pratt, 2006). A friendly climate in the organization motivates members to frequently share and communicate in the organization (Litwin \& Stringer, 1968). This reflects that the employee is more attached with the other members in the organization and sets a 
platform for him or her to share their knowledge. Furthermore, when employees have high sense of affiliation they are more concerned about achieving and conforming to group's norm and expectation. It is expected that affiliation will positively affect peer pressure towards knowledge sharing. As such, we hypothesize:

$\mathrm{H} 2$ : The higher the sense of affiliation, the higher the peer pressure towards knowledge sharing

\subsection{Reciprocal Relationships}

Social exchange theory evaluates the cost and the perceived benefit before engaging in exchange behavior (Huang, Davison, \& Gu, 2008; L. F. Liao, 2008). If the cost is higher than the benefit, one would not participate in the action. Social exchange theory involves several social elements, such as social relationship, loyalty and commitment, and these are not being identified in the economic benefit (Huang et al., 2008; L. F. Liao, 2008). Relationships between employees in an organization have been argued as an important channel for knowledge sharing (Burgess, 2005; Yang \& Chen, 2007). Given that knowledge sharing behavior is being enhanced by mutual relationship between the owner of the knowledge with the one who acquire it, reciprocal relationships stands as a crucial factor for knowledge sharing (Chua, 2003; Ko, Kirsch, \& King, 2005). Reciprocal relationships is defined as employees seeking to establish an ongoing relationship with others in the organization (Bock et al., 2005).

Through reciprocity, individuals who share their knowledge would assume the receiver would reciprocate similar assistance, cooperation and support from others in the future if it is required (Kankanhalli, Tan, \& Wei, 2005; Vithessonthi, 2008). Likewise, Hendriks (1999) also commented that individuals' engagement in knowledge sharing is due to the anticipation of others to reciprocate by sharing their knowledge back in the future. As such, if employees believe sharing knowledge would help to build and strengthen their relationship with other colleagues, they will be more willing to conform to peers' expectations and opinion in term of sharing their knowledge. Based on the review above, the third hypothesis is posited as:

H3: The higher the reciprocal relationships, the higher the peer pressure towards knowledge sharing

The proposed conceptual model is depicted in figure 1 below

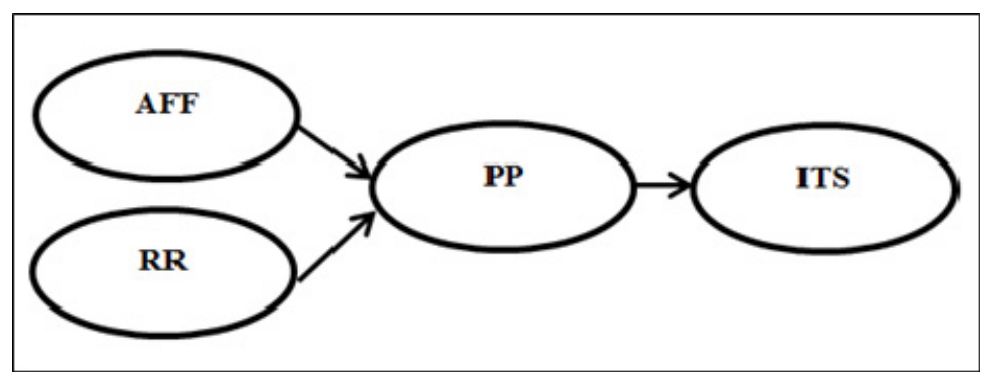

$\mathrm{AFF}=$ Affiliation $; \mathrm{RR}=$ Reciprocal relationships $\mathrm{PP}=$ Peer pressure ITS $=$ Intention to share knowledge

Figure 1. Conceptual model

\section{Method}

An online survey was conducted to collect data from the respondents in various public universities in Malaysia. The sampling strategy followed several stages. Firstly, 10 public universities in Malaysia were selected randomly from the Ministry of Higher Education website. The staff directory listed on each university's website served as the sampling frame. Then, respondents were selected based on systematic sampling from the email collected from respective university's' website. Only academics were selected. A total of 620 email invitations were sent to potential respondents; 37 of these emails were rejected because of unforeseen technical problems. It is assumed that the remaining 583 emails were successfully mailed to the target respondent. Of the 583 emails, 74 have chosen to opt-out from the research and the remaining 274 people in total responded to the survey. However, only 235 questionnaires were usable because 39 were incomplete, hence rendering them unusable for the survey. Therefore, the concluding overall response rate was $40.3 \%$.

\subsection{Measurement and Scale}

The items for the constructs were adapted from past studies and measured on a 5-point Likert scale; ranging from 1 = strongly disagree, $2=$ disagree, $3=$ neither agree nor disagree, $4=$ agree and $5=$ strongly agree. Table 1 list all the constructs, sources and number of items used. 
Table 1. Constructs and items

\begin{tabular}{lll}
\hline Construct & Items & Source \\
\hline Affiliation (AFF) & 4 & McAllister (1995) \\
Reciprocal relationships (RR) & 5 & McAllister (1995) \\
Peer Pressure (PP) & 4 & Kuo \& Young (2008) \\
Intention to Share Knowledge (ITS) & 5 & Van den Hooff \& de Ridder (2004) \\
\hline
\end{tabular}

\section{Results}

\subsection{Respondents' Profile}

The study population consisted of academics in 10 different public universities in Malaysia. Approximately $48 \%$ of the respondents were male and $52 \%$ of them were female. The average age of respondent is 36 years old and approximately $93 \%$ of the respondents had postgraduate qualifications. A majority of the respondents held a lecturer position (50\%), 32\% of them were senior lecturers and approximately $18 \%$ were Professors or Associate Professors.

\subsection{Content Validity and Reliability}

A Cronbach coefficient alpha test was conducted on all four factors to test the reliability of all of the item variables. This was to determine the internal consistency of the scale used. The values of Cronbach Alpha coefficient are depicted below in Table 2. All of the factors were found to have alpha coefficient values of greater than 0.7, which is an acceptable level of reliability (Hair, Black, Babin, Anderson, \& Tatham, 2006; Nunnally, 1978).

Factor loadings within the items and correlation between the constructs were used to determine construct validity. There is no cross loading and all loadings of the constructs were satisfactory with the expected direction (ie 0.6 to 0.94 ), thus supporting the item convergence on the intended constructs. Moreover, the strength of correlation between the constructs were low to moderate (ranged from 0.153 to 0.399 ), thus supporting the discrimant validity of the measures.

Table 2. Validity and reliability

\begin{tabular}{llll}
\hline Construct & Item & Factor Loading & Cronbach's Alpha \\
\hline Affiliation (AFF) & AFF1 & 0.809 & 0.923 \\
& AFF2 & 0.878 & \\
& AFF3 & 0.932 & \\
Reciprocal relationships (RR) & AFF4 & 0.849 & 0.922 \\
& RR1 & 0.785 & \\
& RR2 & 0.883 & \\
RR3 & 0.940 & \\
RR4 & 0.792 & 0.887 \\
Peer Pressure (PP) & RR5 & 0.727 & \\
& PP1 & 0.746 & \\
Intention to Share Knowledge & PP2 & 0.796 & 0.860 \\
(ITS) & PP3 & 0.900 & \\
& ITS2 & 0.730 & \\
& ITS3 & 0.603 & \\
& ITS4 & 0.682 & \\
& ITS5 & 0.887 & \\
\hline
\end{tabular}




\subsection{Structural Model}

Data analysis was performed through Structural equation model by IBM AMOS 20. Structural equation modelling (SEM) is a confirmatory approach to data analysis and it analyses the measurement model as well as the path model (Byrne, 2001).

Different model fit indices are used in SEM as there is no consensus on the performance of adequacy of model fit by a certain fit index. The most commonly used fit indices include: Chi-Square statistic, its degrees of freedom and $p$ value, goodness of fit index (GFI), adjusted goodness of fit index (AGFI), root mean square error approximation index (RMSEA), comparative fit index (CFI) and Tucker Lewis Index (TLI) were used to evaluate the proposed model's overall goodness of fit. As shown in fig. 2, the goodness-of-fit indices of the model include chi-square $=144.692, \mathrm{df}=125, p>0.05, \mathrm{chi} / \mathrm{df}=1.158, \mathrm{GFI}=0.921, \mathrm{AGFI}=0.901, \mathrm{RMSEA}=$ 0.029 , CFI $=0.991$, and TLI $=0.989$. All of the model fit indices appeared in their respective common acceptance levels suggested by prior studies (Chau, 1997; Kline, 2005), hence signifying that the measurement model exhibited a good fit with the data collected.

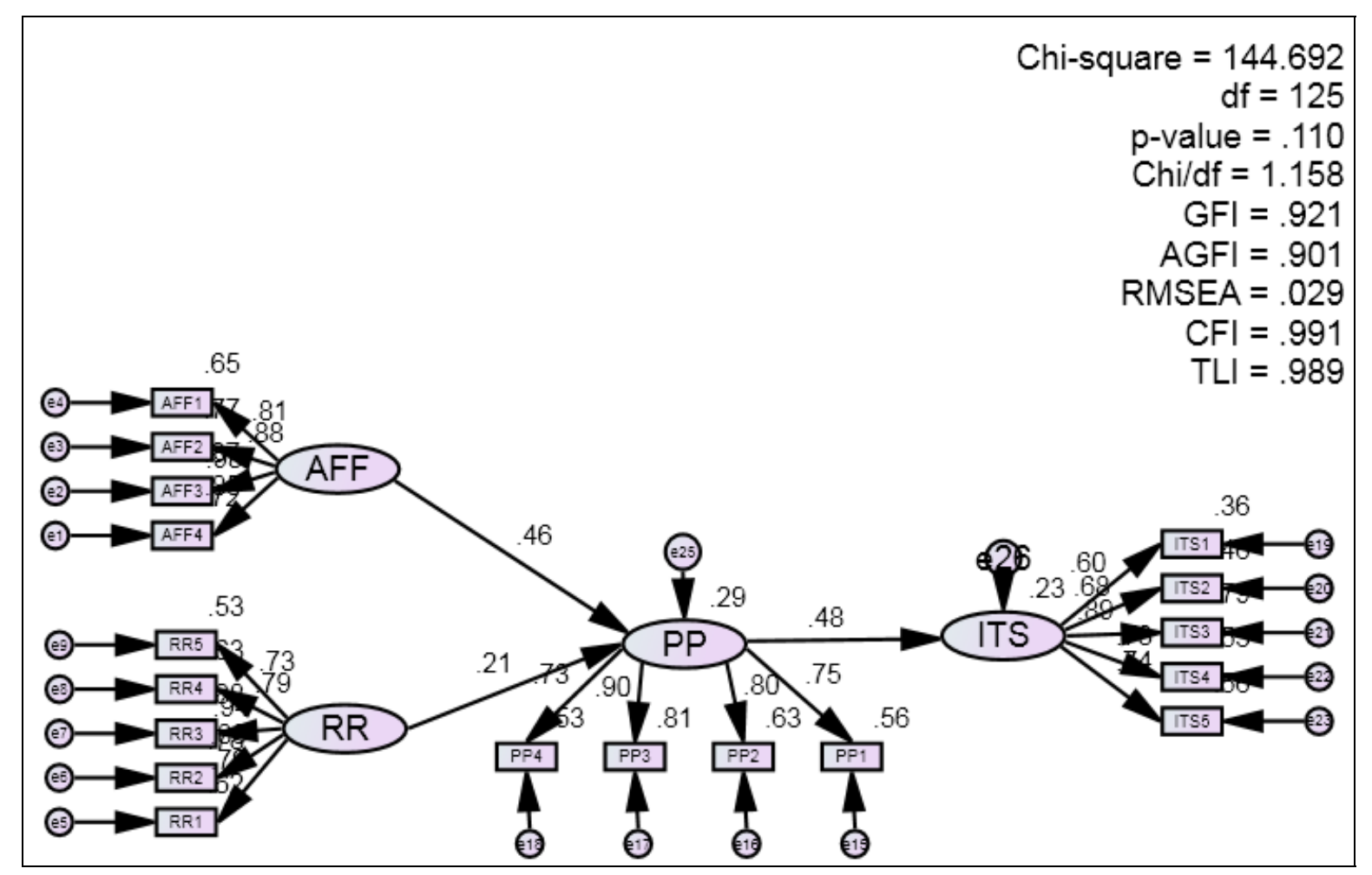

Figure 2. Illustration of structural model

Table 3 below indicates all path coefficients for the model along with its significance. According to results of the SEM analysis, the path coefficient for the model shows that all the constructs under the model are related in right direction and very significant. 
Table 3. Standardized path coefficient critical ratio and standard error

\begin{tabular}{|c|c|c|c|c|c|}
\hline & & & Estimate & S.E. & C.R. \\
\hline PP & $<---$ & AFF & .465 & .067 & $5.553 * * *$ \\
\hline PP & $<---$ & $\mathrm{RR}$ & .214 & .093 & $2.861^{* *}$ \\
\hline ITS & $<---$ & PP & .477 & .074 & $4.885 * * *$ \\
\hline AFF4 & $<---$ & $\mathrm{AFF}$ & .849 & & \\
\hline AFF3 & $<---$ & AFF & .932 & .073 & $17.148 * * *$ \\
\hline AFF2 & $<---$ & $\mathrm{AFF}$ & .878 & .071 & $15.599 * * *$ \\
\hline AFF1 & $<---$ & AFF & .809 & .078 & $13.577 * * *$ \\
\hline RR1 & $<--$ & $\mathrm{RR}$ & .785 & & \\
\hline RR2 & $<---$ & $\mathrm{RR}$ & .883 & .086 & $13.622 * * *$ \\
\hline RR3 & $<---$ & $\mathrm{RR}$ & .940 & .084 & $14.568 * * *$ \\
\hline RR4 & $<---$ & $\mathrm{RR}$ & .792 & .091 & $11.826 * * *$ \\
\hline RR5 & $<---$ & $\mathrm{RR}$ & .727 & .075 & $12.175 * * *$ \\
\hline PP1 & $<---$ & PP & .746 & & \\
\hline PP2 & $<---$ & PP & .796 & .075 & $14.124 * * *$ \\
\hline PP3 & $<---$ & PP & .900 & .111 & $9.164 * * *$ \\
\hline PP4 & $<---$ & PP & .730 & .110 & $7.749 * * *$ \\
\hline ITS1 & $<---$ & ITS & .603 & & \\
\hline ITS2 & $<---$ & ITS & .682 & .113 & $9.157 * * *$ \\
\hline ITS3 & $<---$ & ITS & .887 & .158 & $8.174 * * *$ \\
\hline ITS4 & $<---$ & ITS & .726 & .130 & $7.552 * * *$ \\
\hline ITS5 & $<---$ & ITS & .745 & .114 & $7.687 * * *$ \\
\hline
\end{tabular}

$* * * p<0.001, * * p<0.01$

This study has shown that the proposed model is applicable in the Malaysian public institutions setting to significantly explain intention to share knowledge. Affiliation has stronger effect on peer pressure as compared to reciprocal relationships. The standardized estimates for the path of affiliation to peer pressure towards knowledge sharing effect is 0.46 under the significance level of $p<0.001$. Meanwhile, the standardized estimates for the path of reciprocal relationships to peer pressure towards knowledge sharing effect is 0.21 under the significance level of $p<0.01$. This indicates that $\mathrm{H} 2$ and $\mathrm{H} 3$ are supported. Employees who have high sense of affiliation or belongingness would conform to others' expectation and opinion in regards to sharing knowledge in the organization. Likewise, employees who want to strengthen their work relationship with others would also influence their peers in sharing their knowledge.

On the other hand, we confirmed that peer pressure towards knowledge sharing has an effect towards intention to share knowledge. The standardized estimates of the path of peer pressure towards knowledge sharing intention effect is 0.48 under the significance level of $p<0.001$. Thus, H1 is supported. This implies that an individual with higher tendency to conform to social norms of knowledge sharing goes in tandem with the higher the level of expectation that he or she would engage in knowledge sharing behavior. The finding is in line with previous research (Bock et al., 2005; S. Liao \& Chou, 2012; Vitari, Moro, Ravarini, \& Bourdon, 2007).

\section{Discussion}

This paper has focused on the influence social capital dimensions toward knowledge sharing intention of employees from the public sector in Malaysia. First, from the literature review, three hypotheses were proposed. Structural equation modelling was adopted to analyze and confirmed the hypotheses. The findings show that peer 
pressure has a positive impact towards knowledge sharing intention (H1 supported). In addition, affiliation and reciprocal relationships creates a positive influence over peer pressure towards knowledge sharing $(\mathrm{H} 2$ and $\mathrm{H} 3$ were supported). This paper contributes to the current literature as no research has investigated the influence of affiliation and reciprocal relationship towards peer pressure in knowledge sharing. Based on our findings, we can conclude that both affiliation and reciprocal relationship are crucial in affecting an individual to conform to social norm towards knowledge sharing.

Social exchange and ties among colleagues is important to promote knowledge sharing. Practitioners should create, generate or encourage activities that are centred on advocating bilateral relationships. Messages conveyed should accentuate and highlight the benefits of knowledge sharing which will facilitate the fostering of stronger relationships with others in the university. Based on the study, it is revealed that academics are affected by the expectations of their own superior or even colleagues when deciding whether to participate in knowledge sharing activities. Thus it might prove to be useful to exercise some power on the academics to initiate their knowledge sharing through the formal channel.

This study includes a few limitations. First, the findings of this research must be interpreted with distinct parameters and considerations as the sample adopted in this research is purely based on the context of public universities in Malaysia. Consequently the results are industry specific with reference to the academia world and would unlikely be readily applicable to other industries. To increase the generalizability of the findings, future research could involve different industries. Future studies should also examine whether personal and demographic factors such as gender, ethnicity, job position, type of industry, and country of origin will moderate the effects of affiliation, reciprocal relationships and peer pressure on knowledge sharing behavior.

\section{References}

Ajzen, I. (1991). The Theory of Planned Behavior. Organizational Behavior and Human Decision Processes, 50(2), 179-211. http://dx.doi.org/10.1016/0749-5978(91)90020-T

Bartol, K. M., \& Srivastava, A. (2002). Encouraging Knowledge Sharing: the role of organizational reward systems. Journal of Leadership and Organization Studies, $9(1), \quad 64-76$. http://dx.doi.org/10.1177/107179190200900105

Biggam, J. (2001, January 3-6). Defining Knowledge: an epistemological foundation for knowledge management. Paper presented at the Proceedings of the 34th Hawaii International Conference on System Sciences.

Blacker, F. (1995). Knowledge, Knowledge Work and Organizations: an overview and interpretation. Organization Studies, 16(6), 1021-1046. http://dx.doi.org/10.1177/017084069501600605

Bock, G. W., \& Kim, Y. G. (2002). Breaking the Myths of Rewards: an exploratory study of attitudes about knowledge sharing. Information Resources Management Journal, 15(2), 14-21. http://dx.doi.org/10.4018/irmj.2002040102

Bock, G. W., Zmud, R. W., Kim, Y. G., \& Lee, J. N. (2005). Behavioral Intention Formation in Knowledge Sharing: roles of extrinsic motivators, social-psychological forces, and organizational climate. MIS Quarterly, 29(1), 87-112.

Burgess, D. (2005). What Motivates Employees To Transfer Knowledge Outside Their Work Unit? Journal of Business Communication, 42(4), 324-348. http://dx.doi.org/10.1177/0021943605279485

Byrne, B. M. (2001). Structural Equation Modeling With AMOS: Basic Concepts, Applications, and Programming. London: Lawrence Erlbaum Associates.

Cardador, M. T., \& Pratt, M. G. (2006). Identification Management and Its Bases: bridging management and marketing perspectives through a focus on affiliation dimensions. Academy of Marketing Science Journal, 34(2), 174-184. http://dx.doi.org/10.1177/0092070305284984

Chau, P. Y. K. (1997). Reexamining a model for evaluating information center success using a structural equation $\begin{array}{lllll}\text { modeling } & \text { approach. } & \text { Decision } & \text { 309-334. }\end{array}$ http://dx.doi.org/10.1111/j.1540-5915.1997.tb01313.x

Chay, Y. W., Loh, B. C. H., Menkhoff, T., \& Evers, H. D. (2005). Theorizing, Measuring, and Predicting Knowledge Sharing Behavior in Organizations - A Social Capital Approach. Paper presented at the Proceedings of the 38th Hawaii International Conference on System Sciences, Hawaii. http://dx.doi.org/10.1109/HICSS.2005.622

Christensen, P. H. (2007). Knowledge Sharing: moving away from the obsession with best practices. Journal of 
Knowledge Management, 11(1), 36-47. http://dx.doi.org/10.1108/13673270710728222

Chua, A. (2003). Knowledge Sharing: a game people play. Aslib Proceedings: New Information Perspectives, 55(3), 117-129.

Davenport, H. T., \& Prusak, L. (1998). Working Knowledge: How Organizations Manage What They Know. Boston, M A.: Harvard Business School Press.

Girard, J. P. (2006). Where is the Knowledge We Have Lost in Managers? Journal of Knowledge Management, 10(6), 22-38. http://dx.doi.org/10.1108/13673270610709198

Goh, S. K., \& Sandhu, M. S. (2013). Knowledge Sharing Among Malaysian Academics: Influence of Affective Commitment and Trust. The Electronic Journal of Knowledge Management, 11(1), 38-48.

Grant, R. M. (1996). Toward a Knowledge-Based Theory of the Firm. Strategic Management Journal, 17(Winter Speical Issue), 109-122.

Hair, J. F., Black, W. C., Babin, B. J., Anderson, R. E., \& Tatham, R. L. (2006). Multivariate Data Analysis (2nd ed.). New Jersey: Pearson Prentice Hall.

Harding, T. S., Mayhew, M. J., Finelli, C. J., \& Carpenter, D. D. (2007). The Theory of Planned Behavior as a Model of Academic Dishonesty in Engineering and Humanities Undergraduates. Ethics \& Behavior, 17(3), 255-279. http://dx.doi.org/10.1080/10508420701519239

Hendriks, P. (1999). Why Share Knowledge? The Influence of ICT on the Motivation for Knowledge Sharing. $\begin{array}{llll}\text { Knowledge and } \quad \text { Process } & \text { Management, }\end{array}$ http://dx.doi.org/10.1002/(SICI)1099-1441(199906)6:2<91::AID-KPM54>3.0.CO;2-M

Hong, D. G., Suh, E. H., \& Koo, C. H. (2011). Developing strategies for overcoming barriers to knowledge sharing based on controversial knowledge management: A case study of a financial company. Expert Systems with Application, 38, 14417-14427. http://dx.doi.org/10.1016/j.eswa.2011.04.072

Hsu, C. L., \& Lin, J. C. C. (2008). Acceptance of Blog Usage: The roles of technology acceptance, social influence and knowledge sharing motivation. Information \& Management, 45(1), 65-74. http://dx.doi.org/10.1016/j.im.2007.11.001

Huang, Q., Davison, R. M., \& Gu, J. (2008). Impact of Personal and Cultural Factors on Knowledge Sharing in China. Asia Pacific Journal of Management, 25(3), 451-471. http://dx.doi.org/10.1007/s10490-008-9095-2

Janson, A., \& McQueen, R. J. (2007). Capturing Leadership Tacit Knowledge in Conversations with Leaders. Leadership \& Organization Development Journal, 28(7), 646-663. http://dx.doi.org/10.1108/01437730710823897

Kankanhalli, A., Tan, B. C. Y., \& Wei, K. K. (2005). Contributing Knowledge to Electronic Repositories: an empirical investigation. MIS Quarterly, 29(1), 113-143.

Kline, R. B. (2005). Principles and Practice of Structural Equation Modeling. New York: The Guilford Press.

Ko, D. G., Kirsch, L. J., \& King, W. R. (2005). Antecedents of Knowledge Transfer from Consultants to Clients in Enterprise System Implementations. MIS Quarterly, 29(1), 59-86.

Kuo, F. Y., \& Young, M. L. (2008). A Study of Intention-Action Gap in Knowledge Sharing Practices. Journal of the American Society for Information Science and Technology, 59(8), 1224-1237. http://dx.doi.org/10.1002/asi.20816

Liao, L. F. (2008). Knowledge-sharing in R\&D Departments: a social power and social exchange theory perspective. The International Journal of Human Resource Management, 19(10), 1881-1895. http://dx.doi.org/10.1080/09585190802324072

Liao, S., \& Chou, E. Y. (2012). Intention to adopt knowledge through virtual communities: posters vs lurkers. Online Information Review, 36(3), 442-461. http://dx.doi.org/10.1108/14684521211241440

Lin, H. F., \& Lee, G. G. (2004). Perceptions of Senior Managers Toward Knowledge-sharing Behaviour. Management Decision, 42(1), 108-125. http://dx.doi.org/10.1108/00251740410510181

Litwin, G., \& Stringer, R. A. (1968). Motivation and Organizational Climate. Boston: Harvard University Press.

Lucas, L. M., \& dt ogilivie. (2006). Things Are Not Always What They Seem: how reputations, culture, and incentives influence knowledge transfer. The Learning Organization, 13(1), 7-24. http://dx.doi.org/10.1108/09696470610639103 
Markus, M. L. (2001). Toward a Theory of Knowledge Reuse: types of knowledge reuse situations and factors in reuse success. Journal of Management Inofrmation Systems, 18(1), 57-93.

McAllister, D. J. (1995). Affect- and Cognition-based Trust as Foundations for Interpersonal Cooperation in Organizations. Academy of Management Journal, 38(1), 24-59. http://dx.doi.org/10.2307/256727

Nunnally, J. C. (1978). Pscyometric Theory (2nd ed.). New York: Mc-Graw Hill.

So, J. C. F., \& Bolloju, N. (2005). Explaining the Intention to Share and Reuse Knowledge in the Context of IT Service Operations. Journal of Knowledge Management, 9(6), 30-41. http://dx.doi.org/10.1108/13673270510629945

Van den Hooff, B., \& de Ridder, J. A. (2004). Knowledge Sharing in Context: The influence of organizational commitment, communication climate and CMC use on knowledge sharing. Journal of Knowledge Management, 8(6), 117-130. http://dx.doi.org/10.1108/13673270410567675

Venkatesh, V., Morris, M. G., Davis, G. B., \& Davis, F. D. (2003). User Acceptance of Information Technology: toward a unified view. MIS Quarterly, 27(3), 425-478.

Vitari, C., Moro, J., Ravarini, A., \& Bourdon, I. (2007). Improving KMS Acceptance: the role of organizational and individuals' influence. International Journal of Knowledge Management, 3(2), 68-90. http://dx.doi.org/10.4018/jkm.2007040104

Vithessonthi, C. (2008). Social Interaction and Knowledge Sharing Behaviors in Multinational Corporations. The Business Review, Cambridge, 10(2), 324-331.

Yang, C., \& Chen, L. C. (2007). Can Organizational Knowledge Capabilities Affect Knowledge Sharing Behavior? Journal of Information Science, 33(1), 95-109. http://dx.doi.org/10.1177/0165551506068135

\section{Copyrights}

Copyright for this article is retained by the author(s), with first publication rights granted to the journal.

This is an open-access article distributed under the terms and conditions of the Creative Commons Attribution license (http://creativecommons.org/licenses/by/3.0/). 